\title{
The Potency of Ageratum conyzoides as Biopesticide
}

\author{
Yuliani ${ }^{1, *}$ Yuni Sri Rahayu ${ }^{2}$ \\ ${ }^{I}$ Department of Biology Universitas Negeri Surabaya Surabaya, Indonesia \\ ${ }^{2}$ Department of Biology Universitas Negeri Surabaya Surabaya, Indonesia \\ *Corresponding author. Email: yuliani@unesa.ac.id
}

\begin{abstract}
Ageratum conyzoides, which contains various secondary metabolites such as alkaloids, flavonoids, phenols, hydroquinone, tannins, and essential oils, can be used as herbicide or insecticide. The purposes of this study were to describe the effect of methanol extract of A. conyzoides leaves on mortality of Spodoptera litura larvae and determine $\mathrm{LC}_{50}$ and $\mathrm{LC}_{80}$ of $A$. conyzoides methanol extract. This study used completely randomized design with two factors; concentration of $A$. conyzoides leaves extract $(0 \%, 6 \%, 8 \%, 10 \%, 12 \%)$ and altitude from where A. conyzoides leaves were collected (highland, medium land, and lowland). Experiment was replicated six times. Larvae mortality rate was analyzed using ANOVA followed by Tukey multiple range tests, while $\mathrm{LC}_{50}$ and $\mathrm{LC}_{80}$ was analyzed using probit analysis. Results showed that there was significant differences of $S$. litura larvae mortality rate between A. conyzoides extract concentration $(0 \%, 6 \%, 8 \%, 10 \%$, and $12 \%)$, but no difference was found in the mortality rate between different locations. The higher the concentration of extract, mortality rate of $S$. litura larvae was also increased. Extract at $12 \%$ concentration resulted in highest mortality of $S$. litura larvae at $95 \% . \mathrm{LC}_{50}$ of A. conyzoides extract was found to be $3.45-3.87 \%$, while $\mathrm{LC}_{80}$ was $7.76-8.18 \%$.
\end{abstract}

Keywords: Potency, Ageratum conyzoides, Biopesticide

\section{INTRODUCTION}

Plant secondary metabolites, such as tannins, alkaloids, flavonoids, saponins, and phenols, are produced by plants and used for defense mechanism against insects, because these compounds are able to inhibit insect metabolism process [1]; [2]. Insecticidal secondary metabolites effects including early death, lowering growth rate, shortening lifespan, abnormality in morphology, and restlessness and other abnormal behaviors.

Secondary metabolites, such as phenols, that act as feeding deterrents to inhibit insect development. Some phenols also attract natural enemies of the insect pests so the predators of insect will come and kill the insect [3]. Phenols can also dissolve lipids from cell walls, which affect cytoplasmic membrane integrity, thus inducing cell lysis and inhibit ATP-ase binding to cell membrane. Saponins can be used as insecticide; in addition to its ability to control Aedes aegypti larvae, saponins can also induce mortality in adult mosquitoes and act as repellant that prevent them from approaching.
Ageratum conyzoides, or locally known as babadotan, is a plant traditionally used to control insect pest [4] [5]. This plant contains various secondary metabolites, such as saponins, polyphenols, coumarins, eugenols, essential oils, alkaloids, tannins, sulfur, flavonoids, alkaloids, chromenes, benzofurans, and terpenoids (monoterpenes and sesquiterpenes) [6]. Study of A. conyzoides leaf oil as insecticide showed that at $0.5 \%$ concentration, it could induce mortality in more than $90 \%$ Spodoptera litura caterpillar [7]. Jaya and his colleagues reported that Essential oils (EOs) from A. conyzoides L., could be used against Tribolium castaneum [5].

A. conyzoides Linn contain alkaloids compounds with chemical structures in the form of Lycopsamin and Echinatin, which have been developed as natural pesticides. Both of these compounds are toxic against Lepidoptera insects, Aedes aegypti mosquito larvae and able to eradicate pests Mahogany shoot [8]. Renuga and Sahayaraj who studied ethanol extract of Ageratum genus concluded that $A$. conyzoides and A. vulgaris extract could significantly lower total protein of S. litura at concentration of $0.01 \mu \mathrm{L} /$ insect [6]. Sari and 
Armayanti also reported the similar results that $A$. conyzoides extract has a high antifeedant effect and can used for controlling Spodoptera sp. [9]

Plant extract was known to have pharmacology effect beside insecticidal and nematicidal activities [10]; [11]. Okunade explained that bioactivity of $A$. conyzoides was highly varied. Methanol extract of its leaves could be applied as antimicrobial agent, while essential oils of $A$. conyzoides had anti-inflammatory, analgesic, and antipyretic effect [10]. Extract of this plant was also able to induce abnormal morphogenetic in mosquito larvae. Based on this elaboration, $A$. conyzoides could possibly be applied as botanical insecticide to control insect pest.

Secondary metabolites are formed within plants as part of defense mechanism against threat in their ecosystem. Because of that, level of secondary metabolites in each plant are affected by its environment, such as elevation, rainfall, and temperature [12]. Furthermore, environment factor is thought to interact with genetic factor in the expression of secondary metabolites; thus, production and secretion of secondary metabolites are affected by temperature, photoperiod, soil condition, microorganism, and nutrient status [13]. This implies that plants applied as biopesticide must be cultured in accord with its habitat as to maximize secondary metabolites production.

A. conyzoides extract in the current study was applied to $S$. litura larvae. The attack of this caterpillar caused damage up to $12.5 \%$ and more than $20 \%$ cultivated plants at age more than 20 days after planting [14]. Up to today, S. litura was controlled widely using synthetic pesticide. However, because of excessive use, insect resistance towards insecticide emerged. Because of that, to control $S$. litura population, biopesticide from secondary metabolites was applied [2] [15]. Based on this background, the purposes of this study were to describe the effect of $A$. conyzoides leaf methanol extract on $S$. litura larvae mortality and determine LC50 and LC80 of A. conyzoides leaf extract.

\section{METHODS}

A. conyzoides leaves collected from three different altitude (lowland (28.4-31.7 $\mathrm{m}$ above sea level) in Bangkalan, medium land (725-937 $\mathrm{m}$ above sea level) in Trawas, and highland (1300-1323 $\mathrm{m}$ above sea level) in
Batu) were dried for 10 days at room temperature, then grounded and sieved with a 40-mesh sized sieve into dried leaf powder. Powdered leaf was extracted using modified procedure of Dorman and Hiltunen (16). Simplicia was macerated with petroleum ether (1: 4 $\mathrm{w} / \mathrm{v}$ ) at room temperature for 24 hours, then dried residue was extracted with methanol $(1: 15 \mathrm{w} / \mathrm{v})$ using Soxhlet extraction at $65^{\circ} \mathrm{C}$ for 3 hours. The solvent was evaporated under low pressure using a rotary evaporator to obtain methanol extract.

The target organism used in the test was instar 2 larvae of $S$. litura. The concentration of plant extracts biopesticide was $0 \%$ (negative control), 6\%, 8\%, 10\%, and $12 \%$. Each concentration was replicated three times with 10 larvae for respective replication. Methanol extract was diluted to using 10\% DMSO until all desired concentration was obtained. Larvae was fed cabbage leaves during experiment. Cabbage leaves was cut into circular shape, weighed $0.1 \mathrm{~g}$, and placed in prepared container. After larvae had acclimated, $0.2 \mathrm{~mL}$ of methanol extract were administered into each container. Container was closed and observed daily for 7 days. Parameter recorded was larvae mortality (number of dead caterpillars per day). Data of mortality number was analyzed statistically using two-way ANOVA, while LC50 and LC80 were analyzed using probit analysis.

\section{RESULTS}

\subsection{Mortality Rate}

Biopesticide of $A$. conyzoides leaf methanol extract was tested against Spodoptera litura larvae to observe the effect in larvae mortality. Result of test is presented in Table 1.

Percentage of mortality was recorded 24 hours after the start of treatment up to $7^{\text {th }}$ day of experiment (Table 1). Administration of $A$. conyzoides extract at various level showed that $12 \%$ concentration resulted in highest mortality rate of $S$. litura. Extract concentration of $8 \%$ from lowland and highland A. conyzoides could induce mortality of S. litura at $79.58 \%$. At $10 \%$ concentration, medium land $A$. conyzoides extract was able to cause $88.33 \%$ larvae mortality. Highest rate of $S$. litura mortality was found from extract of A. conyzoides leaves collected from medium land, followed by highland and lowland.

Table 1. Percentage of Spodoptera litura larvae mortality (in day 7) given various concentration of Ageratum conyzoides leaf methanol extract from various altitude of habitat

\begin{tabular}{lccccc}
\hline \multirow{2}{*}{ Altitude of habitat } & \multicolumn{5}{c}{ Mortality rate of S. litura at extract concentration (\%) } \\
\cline { 2 - 5 } & $0 \%$ & $6 \%$ & $8 \%$ & $10 \%$ & $12 \%$ \\
\hline Lowland & $18.33 \pm 7.5$ & $75.51 \pm 0.0$ & $79.58 \pm 8.1$ & $83.67 \pm 8.1$ & $91.83 \pm 8.1$ \\
Medium land & $28.33 \pm 11.6$ & $61.67 \pm 4.1$ & $76.67 \pm 5.2$ & $88.33 \pm 11.7$ & $95.00 \pm 5.4$ \\
Highland & $18.33 \pm 14.7$ & $71.43 \pm 15.1$ & $79.58 \pm 16.3$ & $85.71 \pm 11.7$ & $91.83 \pm 8.2$ \\
\hline
\end{tabular}


Two-factor variant analysis showed that there was significant difference among $A$. conyzoides extract concentration administered $(0 \%, 6 \%, 8 \%, 10 \%$, and $12 \%$ ) with $\mathrm{F}$ value (148.80) > F statistic (2.493). However, no significant difference of larvae mortality rate between different altitudes from where $A$. conyzoides were collected, in which $\mathrm{F}$ value $(0.473)<\mathrm{F}$ statistic (3.110).

\section{2. $L C 50$ and $L C 80$}

Based on mortality rate of $S$. litura, probit analysis was performed to determine LC50 and LC80 of $A$. conyzoides leaf methanol extract, which is presented in Table 2.

Table 2. LC50 and LC80 of A.conyzoides methanol extract on Spodoptera litura larvae

\begin{tabular}{|c|c|c|}
\hline \multirow{2}{*}{ Habitat altitude } & \multicolumn{2}{|c|}{$\begin{array}{c}\text { Ageratum conyzoides extract } \\
\text { concentration (\%) }\end{array}$} \\
\hline & $\mathrm{LC}_{50}$ & $\mathrm{LC}_{80}$ \\
\hline Lowland & $3.45 \pm 0.48$ & $7.76 \pm 0.46$ \\
\hline Medium land & $3.87 \pm 0.46$ & $8.18 \pm 0.45$ \\
\hline High land & $3.51 \pm 0.48$ & $7.81 \pm 0.46$ \\
\hline
\end{tabular}

Based on $S$. litura mortality, $\mathrm{LC}_{50}$ of $A$. conyzoides extract collected from lowland was $3.45 \%$, implying that at that level, extract could induce $50 \%$ larvae mortality. Extract $\mathrm{LC}_{50}$ of $A$. conyzoides collected from medium land was $3.87 \%$, while from highland was $3.51 \%$. Extract $\mathrm{LC}_{80}$ of $A$. conyzoides collected from lowland was $7.76 \%$, from medium land was $8.18 \%$, and from highland was $7.81 \%$, meaning that at those levels, A. conyzoides could induce mortality in $80 \%$ of $S$. litura larvae.

\section{DISCUSSIONS}

Plants have evolved various mechanisms to defend themselves against insects, including the production of specialized metabolites that act as natural insecticides [2]. Anti-insect chemicals such as secondary metabolites that produced by can be effective in the battle against insects through different modes of action, ranging from damaging the exoskeleton of the insect, to preventing the insect from feeding [2].

Active compounds in plants, such as coumarins, phenols, terpenoids, polyphenols, saponins, and alkaloids, are known from various previous studies to have effect as antifeedant and growth inhibitor in insect that cause chronic toxicity and mortality in larvae [17]. Secondary metabolites such as furanocoumarins (in particular, the major substance imperatorin) are compounds that toxic for S. litura larvae, caused by inhibition of their growth. This larval growth inhibition could be caused not only by the antifeedant effect, but also by possible histological changes in the alimentary canal of the insect $[18,19]$.

Various studies showed that plant secondary metabolites could be used as pesticide to control $S$. litura. For example, study by Yooboon and his colleagues that study about A plant-based extract mixture for controlling $S$. litura (Lepidoptera: Noctuidae). Based on those studies, it was found that the ethanolic crude extracts of $P$. retrofractum and $A$. calamus mixtures could be used as the pesticidal compound and to develop a binary mixture formulation for controlling lepidopteran pests [18]. Pavela [20] observed the effect methanol extracts from 134 plants in inducing mortality of instar $4 \mathrm{~S}$. litura larvae. The result showed that three plants from family Asteraceae, Artemisia compresis, Camelia sinensis and Eupatorium cannabinun, applied respectively as biopesticide at dose of $15 \mathrm{mg} / \mathrm{g}$ were able to cause $100 \%$ mortality of $S$. litura larvae (observation performed after $5^{\text {th }}$ day application).

The application of botanical pesticides on organic farming is expected to conserve natural resources and agricultural productivity in long term, ensure minimal environmental impact, produce optimum crops with minimal chemical input, and provide proportionate economic benefits for farmers. Controlling pests permanently is expected to help create balanced agricultural ecosystem and sustainable agriculture.

\section{CONCLUSIONS}

Based on results and discussions, it can be formulated some conclusions such as followed:

1. Application of $A$. conyzoides extract at $12 \%$ concentration produced the best result in inducing $S$. litura mortality, at $95 \%$. However, no difference was found in $S$. litura mortality given extract of $A$. conyzoides from different altitude of habitat; highland, medium land, and lowland.

2. Methanol extract of A. conyzoides had LC50 level of $3.61 \%$ and LC80 level of $7.91 \%$ in inducing $S$. litura larvae mortality.

\section{REFERENCES}

[1] P.H.G. Cruz, R.L. Nuñez, C.A. Anulacion, N.A. Gregorio, K. Iniwan, E.J. Nolasco, R.M. Pallarca, K.G.D. Waing, Insecticidal Property And Phytochemical Screening of Mahogany (Swietenia Macrophylla King) Leaves, Barks And Seeds as an 
Alternative Insecticide Against Fungi Growing Termites, IJBPAS, 7(8), 2018, pp. 1521-1528.

[2] R.W.J. Kortbeek, M. van der Gragt, P.M. Bleeker, Endogenous plant metabolites against insects, Eur J Plant Pathol, 154, 2019, pp. 67-90.

[3] A.R. War, G.K. Taggar, B. Hussain, M.S. Taggar, R.M. Nair, H.C. Sharma, Special Issue: Using Non-Model Systems to Explore Plant-Pollinator and Plant-Herbivore Interactions, AoB PLANTS, 2018. Available at https://academic.oup.com/aobpla

[4] G.A.S. Benson, A.A. Obadofin, J.M. Adesina, Evaluation of plant extracts for controlling insect pests of pepper (Caspicum spp.) in Nigeria humid rainforest, New York Science Journal, 7(1), 2014, pp. 39-43.

[5] J.P. Singh, B. Prakash, N.K.J. Dubey, Insecticidal activity of Ageratum conyzoides L., Coleus aromaticus Benth. and Hyptis suaveolens (L.) Poit essential oils as fumigant against storage grain insect Tribolium castaneum, Herbst Food Sci Techno., 51(9), 2014, pp. 2210-2215.

[6] F.B. Renuga, K. Sahayaraj, Influence of botanicals in total head protein of Spodoptera litura (Fab.), Journal of Biopesticides, 2(1), 2009, pp. 52-55.

[7] R. Balfas, W. Mahrita, Pengaruh Ekstrak Tanaman Obat Terhadap Mortalitas dan Kelangsungan Hidup Spodoptera litura F. (lepidoptera, Noctuidea), Buletin Litro Balai Penelitian Tanaman Obat dan Aromatik, 20, 2009, pp. 148156.

[8] I. Kinasih, A. Supriyatna, R.N. Rusputa, Uji Toksisitas Ekstrak Daun Babadotan (Ageratum conyzoides Linn) Terhadap Ikan Mas (Cyprinus carpio Linn.) Sebagai Organisme Non-Target, Edisi VII(2), 2013, ISSN 1979-8911.

[9] D.E. Sari, A.K. Armayanti, Efek Antifeedant Ekstrak Ageratum conyzoides L. Terhadap Spodoptera sp., Jurnal Agrominansia, 3(2), 2018.

[10] A.L. Okunade, Ageratum conyzoides L. (Asteraceae), Fitoterapia, 73(1), 2002, pp. 1-16.

[11] M. Pavaraj, K. Karthikairaj, M.K. Rajan, Effect of leaf extract of Ageratum conyzoides on the biochemical profile of blackgram Vigna mungo infected by rootknot nematode, Meloidogyne incognita, J. Biopest., 3, 2010, pp. 313-316.

[12] A. Khan, M. Taqi, M.M. Firoz, Status of Secondary Plant Product Under Abiotic Stress: an Overview, Journal of Stress Physiology \& Biochemistry, 7(2), 2011, pp. 75-98.
[13] S. Sharafzadeh, K. Ordookhani, Influence of Carbon Dioxide Enrichment on Accumulation of Secondary Metabolites in Plants, Australian Journal of Basic and Applied Sciences, 5(11), 2011, pp. 1681-1686.

[14] Pracaya, Hama Penyakit Tanaman (Edisi Revisi), Penebar Swadaya, Jakarta, 2008.

[15]P. Bhatt, N. Thodsare, R.P. Srivastava, Toxicity of some bioactive medicinal plant extracts to Asian army worm, Spodoptera litura, Journal of Applied and Natural Science, 6(1), 2014, pp. 139-143.

[16] H.J.D. Dorman, R. Hiltunen, Fe(III) reductive and free radical-scavenging properties of summer savory (Satureja hortensis L.) extract and subfractions, Food Chemistry, 88, 2004, pp. 18871892.

[17] H.J. Cottrell, Pesticides on Plant Surfaces, Society of Chemical Industry, New York, 1987.

[18] T. Yooboon, A. Pengsook, A. Ratwatthananon, W. Pluempanupat, V.A. Bullangpoti, Plant-based extract mixture for controlling Spodoptera litura (Lepidoptera: Noctuidae), Chem. Biol. Technol. Agric., 6(5), 2019.

[19] S.K. Lakshmanan, K. Krishnappa, Elumalai, Certain Plant Essential Oils Againts Antifeedant Activity of Spodoptera litura, 2012.

[20] R. Pavela, Screening of Eurasian Plant for Insecticidal and Growth Inhibition Activity Against Spodoptera litura larvae, African Journal of Agricultural Research 6(12), 2011, pp. 28952907. 